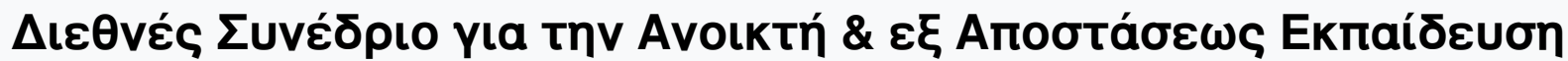

Tón. 5, Ap. 1A (2009)

Open and Distance Education for Global Collaboration \& Educational Development

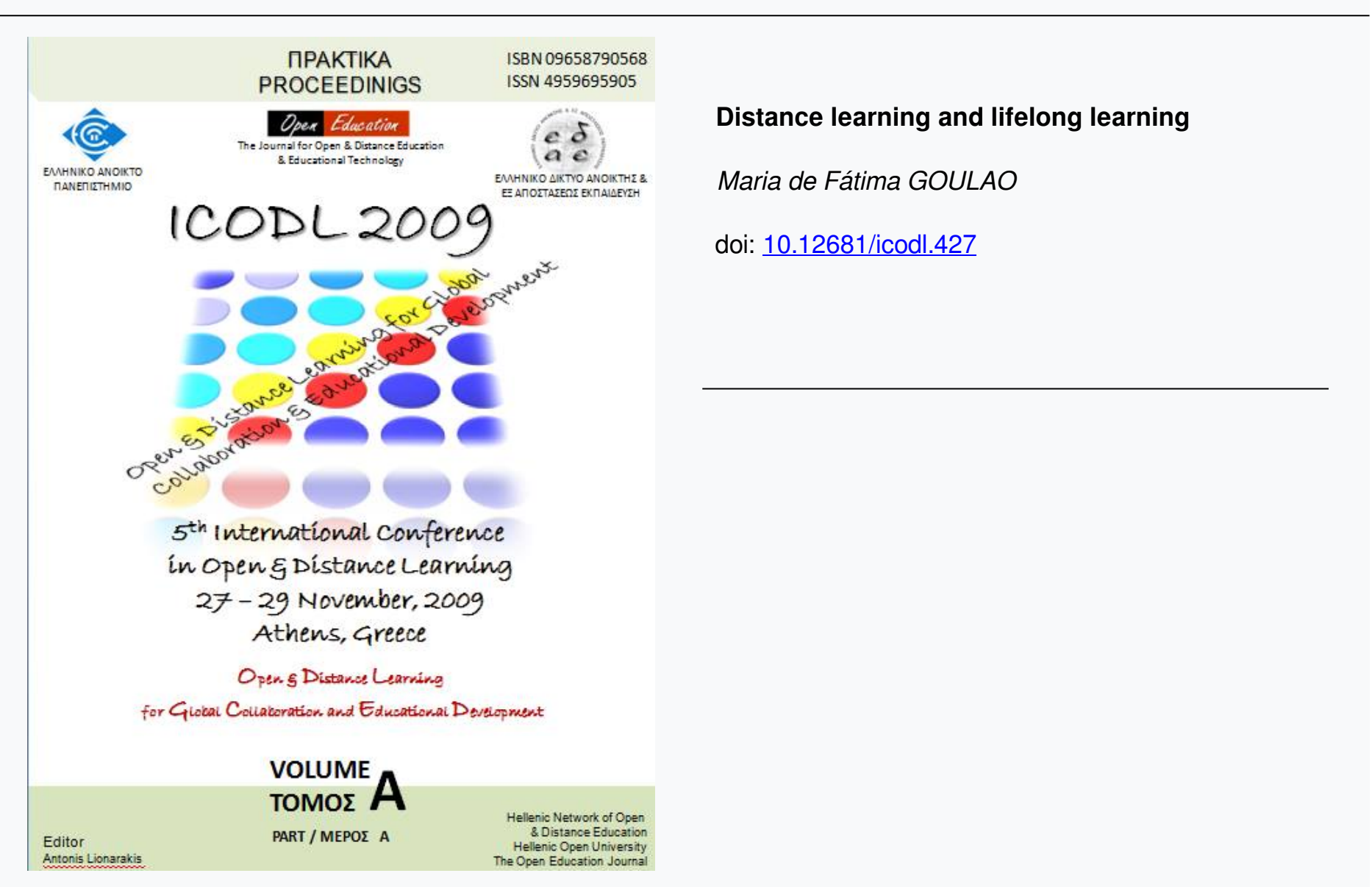

Distance learning and lifelong learning

Maria de Fátima GOULAO

doi: $10.12681 /$ icodl. 427

Open and Distance Ec 


\title{
Distance learning and lifelong learning
}

\author{
Maria de Fátima GOULAO \\ Universidade Aberta, Portugal \\ Assistant Professor, Phd \\ fgoulao@univ-ab.pt
}

\begin{abstract}
One way to education reaches more people, whether they are in a higher education or not, whether they are at the beginning of their formation or updating their knowledge is through the distance learning. It has many specific characteristics that make a person a privileged partner in the whole process.

Many of the students of the distance learning are no longer young and have their jobs and families. By these reasons they have to coordinate the different areas of life which are mutually influenced. The reasons that take them to embrace a project of distance learning are diversified. Some students bet on getting an upper academic level because they can reach a better place of work while others only want to have a bigger cultural degree.

Our study pretended to know the reasons that induce people to choose this education system and how they evaluate the elearning, in general. A sample of 80 distance learning students of both sexes was used. As an instrument to collect data, in the first question, it was used an open answer questionnaire in which was requested the 3 main reasons that took the inquired to choose distance learning. The analysis of the answers was made based in the technique of content analysis. In the elearning evaluation it was used a qualitative scale.
\end{abstract}

Key-words: distance learning, adults' learns, lifelong learning

\section{Introduction}

\section{The concept of lifelong learning}

Societies are constantly changing. These changes are felt on different levels, particularly concerning the knowledge one, provoking a need of adjustment within society and individuals.

On this perspective, knowledge constitutes itself as the support and the stimulating element of societies' development, due to the reach of the changing rhythm that societies have been suffering.

Side by side with this concern appears another one which is the need to recycle people, by giving them the ways to adjust to this new society and also to the exigencies that alterations and new know ledges put to those who are already at the Job market. In fact, society and the world of work have been subjected to a huge change and evolution due to the fast technologic development as well as to globalization.

Because of this panorama the traditional phases of a worker's life: formation employment - retirement are no longer the same. The bet must be on "human capital", insisting on the change of mentalities and challenges that this "new" society implies. 
This preparation must pass through developing of personal competences which give those that will need it, the opportunity to be apt to answer different solicitations.

This preparation must pass through developing personal competences which habilitate those that need it to adjust and to answer different solicitations.

Allied to those two versions we find another reality related to a big number of individuals which early abandon school. Graphic 1 give us those rates at EU-27. In spite of this situation have been improving during the last years, most part of the countries are still over the reference value for the EU for 2010; actual 15\% against $10 \%$ previewed.

\section{Graph 1 Early School Leavers}

Share of the population aged 18-24 with only lower-secondary education and not in education or training, 2000-2006

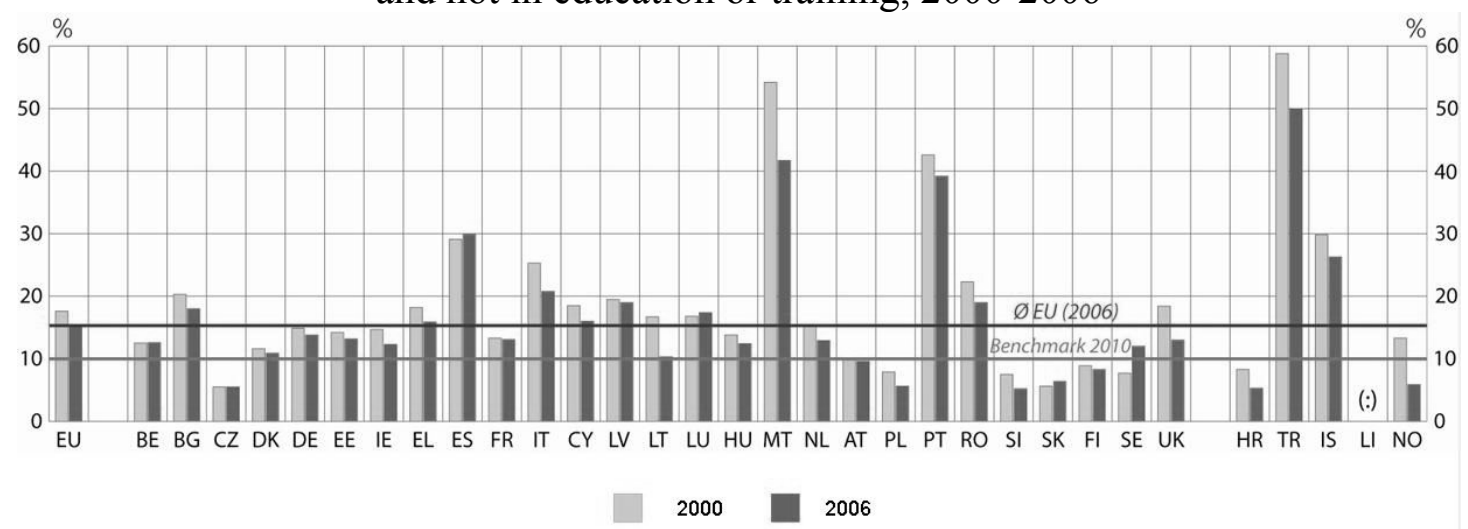

(Source: Council of the European Union, 2008) $)^{[1]}$

However, we know that the analogy between instruction and lifelong learning, employment and economic development are stronger. So, economic and social instability as well as the knowledge 'impact within society reinforced learning importance through life as "all learning activity in any time of life with the scope of improving know ledges, adjustments and competences in a civic, social and/or related to work". (European Commission, 2001, p.11)

Education and Formation have repercussions felt at individual levels as well as communitarian /social development. Populations' social awareness, through the transmission of knowledge as well as formation, may allow a real development of the Economy by giving a best fit between which is necessary and the potentialities of people involved.

Understanding the reality which surrounds us and also the implication that it has in each one of us it is an important step to find out answers.

Betting on education / formation takes us to a best performance of the tasks, a better adjustment of the intervenient, a better social awareness and a better participation inside community.

The different intervention made on the research and politic levels point to the learning importance through life in order to raise market employment, reinforce social inclusion, active citizenship and personal development.

This notion includes the whole process of formal learning, as well as non formal and informal, because we must be aware that even that learning does not develop within the formal space built to this situation, it exists. 
Initial formation must be faced as the first degree to reach social and professional insertion. However, we cannot forget that it is necessary to go on developing and actualizing competences to a better adjustment required by society or by professional reconverting.

So, we come in the adult's learning field. This one can be understood as "all ways of learning done by adults after abandoning the initial education and formation, independently the level they had reached" (Council of the European Union, 2006, p.1). This definition may also include the notion of Higher Education.

The importance that this subject has in The European Union can be seen on the effort done by adjusting the same politics in order to render education systems as well as the reorganization of the competences that help mobility and integration of individuals within the European space. On the other hand, support and promotion to the lifelong learning too. About the Higher Education we find important the Bologna declaration which, in 2001, was added a line of action about lifelong learning.

The framework of qualifications for the European Higher Education Area, adopted by the ministers in 2005, during the Bergen Conference includes the "learning competences".

In 2006, the European Parliament and the European Union Council recommended to memberships to "(...) develop the provision of key competences for all as part of their lifelong learning strategies, including their strategies for achieving universal literacy (...)" (Official Journal of the European Union, 2006, p.11). In this sphere of action it was developed and approved The European Qualifications Framework for Lifelong Learning. It allows, among other things, “(...) using learning outcomes as a common reference point, the Framework will facilitate comparison and transfer of qualifications between countries, systems and institutions and will therefore be relevant to a wide range of users at European as well as at national level." (European Commission, 2008, p.4)

According with the results of the survey Education and Training of Adults, in 2007 about one third (30.9\%) of Portugal's population aged between 18 and 64 participated in one activity of formal or informal learning, at least (Statistics Portugal, 2008). However, if it is important to evidence that participation in formative activities, the analysis of the reasons for not participating in this kind of activities or of its obstacles it is also important. The reasons given by participants in this study and that in the year 2007 "did not participate but wanted to participate" in training activities are in the following table:

Table 1 Main reason for non-participation in education and training

\begin{tabular}{l|c|}
\hline Reasons & $\%$ \\
\hline Total & $\mathbf{1 0 0}$ \\
\hline Missing time due to family responsibilities & 20,5 \\
\hline Lack of suitable close training & 18,1 \\
\hline Training was in the work hour & 13,1 \\
\hline Very expensive training & 12,9 \\
\hline Lack of support from employer & 8,1 \\
\hline
\end{tabular}




\begin{tabular}{l|r|}
\hline Lack of pre-requirements & 6,8 \\
\hline Due to his health & 2,3 \\
\hline $\begin{array}{l}\text { Lack of trust / of security with the idea of going "back to } \\
\text { school" }\end{array}$ & 1,4 \\
\hline Due to their age & 1,2 \\
\hline Another & 15,7 \\
\hline
\end{tabular}

\section{New public for Higher Education}

This new reality has a new public on the instruction system which brings new and different challenges to it.

About Higher Education we can group these new "clients" in three categories (Teichler, in UNESCO, 2005) :

- Postponers: Here are inserted the individuals who had Access to upper instruction at the end of High School, but that for several reasons did not follow their studies

- Returners: Group of individuals that entered Upper Instruction but that need to upgrade their knowledge for Professional or cultural reasons;

- Second chance: Group of individuals who could not yet benefit of the instruction system and that have now the opportunity.

These different groups have common denominators such as handicaps concerning economic, academic, cultural and psychological spheres.

Speaking about the economical level, as they can be unemployed persons or persons with lower incomes, they have to face expenses for studying again. About academic sphere we can find persons who don't have the qualifications to enter at Higher Education. At last, cultural and psychological spheres. Many of those persons had to leave school at the proper time, bringing with them an unsuccessful story that may influence their return. Also the "return to school" can unleash an idea of childishness creating resistance.

So it is recognised each time more and more the value of the importance of upper instruction and the adequate research, in order to the formation of the critic mass of qualified and cult people, in a way to guarantee the development of the countries.

\section{Adult students}

This question has already some years. This system lead to the development of the movement named andragogy, meaning, "the art of teaching adults". The main name is attached to Malcolm Knowles. For him adults are self-responsible and they expect to have the responsibility to take decisions. This movement outs adult against young student (child or teenager), so, andragogy versus pedagogy.

Andragogy is based on essential presuppositions concerning adult learners (Knowles, 1990). Lets see what are these presuppositions:

1. Self-concept of the learner. Once adults reach a stage where they possess their lives responsibility, they develop a psychological need to be seen and treated by others as being able to self-manage. 
2. Experience role. Adults are going to a learning situation with a bigger number and more diversified experiences than that of children.

3. Orientation to learn: Adults are ready and motivated to learn if the results of that learning are related to their lives context and if that this will help them to deal with solving problems.

4. Need to know. Adults need to know the reason why they have to learn a specific subject before getting involved.

5. Motivation. The best motivation is inherent, such as self-esteem, quality of life or a job progression.

Rogers' (1985) studies also point to the benefits that adults can obtain through learning when they become responsible for it by defining objectives, selecting the sources as well as study materials, establishing the whole stages and giving a certain rhythm by evaluating learning. .

Works on psychology and education sciences have been demonstrating that the frontiers between one universe and the other are not so rigid and clear. (Bourgeois \& Nizet, 1999). On the contrary, we can find on children or young learners some characteristics that according to andragogy would be exclusive of those adults and the contrary is also true. For instance, we speak about concepts as "the need to know" or the "will to learn", which also perform a primordial role in learning of children and young.

So it seems that the most important in the whole learning situation is that we have to consider these factors and that the person is able to learn, not only being a receptacle of information but a person who has a whole story and life Project which make $\mathrm{him} / \mathrm{her}$ move on. "For adults the living experiences are an important support of their learning” (Costa \& Silva, 2000, p.673).

\section{Adults' education}

Adults' education is oriented to give answers for several needs which appear inside society and that change from country to country and time to time. In an effort to follow these changes, people are compelled to explore different strategies and ways so they can give more effective answers to new challenges that society "give them" (Malglaive, 1995).

The adult learner involvement in formation is done on his story and personal life project. The decision which takes an adult to get involved in a formation process is, in one way or another, attached to a personal, professional and/or social project, meaning that the adult learner involvement takes to expectations which can even be totally conscientious but that, in the end, he/she expects to be well succeeded.

For Cross (1981) an adult learner invests with formation because expectations are so strong and seen as to be important to him that formation is a way to obtain them.

This way, getting involved in formation mobilizes not only cognitive aspects as well as affective ones.

Different researches agree with this aspect: the individual project is essential and vital, to take the person to begin the formation process. Meaning that the project represents the main source of energy for all that will happen.

However, speaking about formation, the involvement of an adult learner, may be complicated because of other parameters. Sometimes the adult learner faces problems like having other responsibilities / compromises besides formation, like family, professional and even social reasons. 
Difficulties don't remain here and we can find them on the lack of time or economic availability to obtain a successful formation.

\section{Distance Learning}

Besides that, geographic dispersion as well as individual, family, economic or health factors made distance learning a education system which is an important allied concerning formation and development of individuals so also to societies, weather we are speaking about a traditional one or those of technology (Aretio, 2002).

Distance learning is based on a dialogue between professor and student where there is no share of physical spaces and where the time may not coincide. The student learns independently.

The methodologies of distance learning are based on a learning model that suppose the existence of adult learners who have a maturity level as well as enough motivation which will allow them to get involved in a self-learning process.

That way learning distance instruction must be oriented to allow to the learner autonomy which implies, among other aspects, individualised interactions and a great discipline.

Distance Learning is usually based on the individualised formation and in general, it is about a philosophy which recognises the learner to have the power on his own formation. How? By building up pedagogic supports and ways of transmitting knowledge which will allow him, more and more each time, to become responsible and autonomous. When speaking of this kind of system it puts autonomy not as a selection motive but as a formation goal. So, we have:

Figure 2 Distance learning

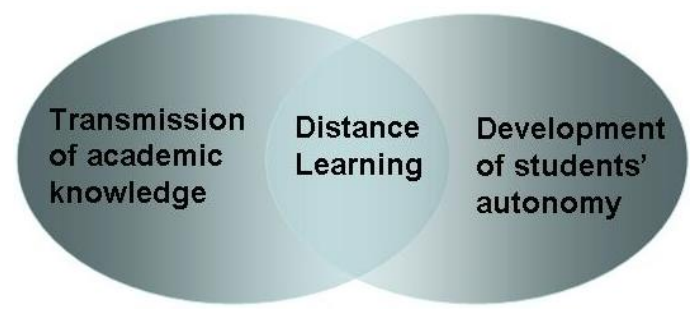

So we can say that one of the ways to reach more people, whether they have an upper level or not, whether they are at the beginning or actualizing knowledge it is through distance learning. This has very specific characteristics which take it to be a privilege partner in the whole process. Those characteristics are to overpass the space-time constraints on the face-to-face instruction. So it adopts strategies which allow to flexibly spaces, times, rhythms, styles and ways of learning (Goulão, 2002).

Distance learning formation usually gives answers to this new need of individualization. It offers, to those who are interested, whether their initial motivations are, this kind of system especially allows to free persons of any spacetime constraints imposed by the traditional ones: 
Figure 3 Some aspects of Distance learning

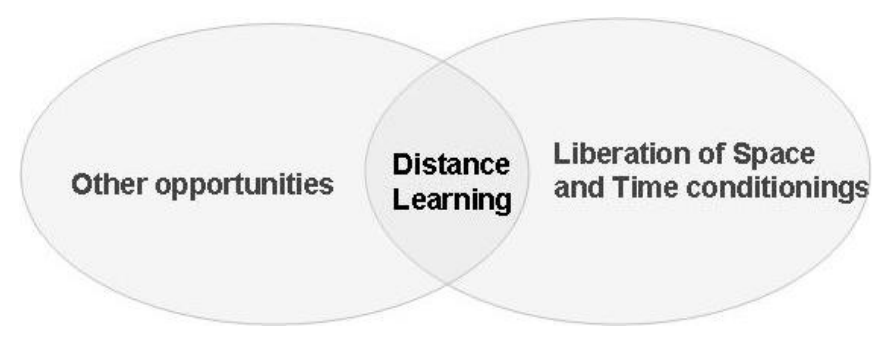

So, it is necessary to adopt promotional knowledge strategies having as a scope the production of autonomous individuals, socially responsible and competitive inserted in a world market, over and over more specialized.

So, we can say the functions of an Open University are:

- Help economic development

- To respond to public demand

- To widen access to new group of students

- Intervention to change higher education systems

- Major social change

\section{Methodology}

\section{a. Objective}

This investigation's objective as follows:

- To analyze the reasons why people choose this education system.

- Evaluation of elearning, in general

\section{b. Sample}

Our study's sample was done from students who sent us well done questionnaires, in all 80. In the sample we have students representing several courses / areas of knowledge (Social sciences, European Studies and Applied Languages). About the gender of the subjects of the sample, $33 \%$ were male and $67 \%$ female.

The following table (Table 2) shows us the sample's information from the point of view of the variables - Age and Number of years attending distance learning.

Table 2 Characteristics of the sample

\begin{tabular}{|l|r|r|}
\hline & Age & $\begin{array}{c}\text { Number of years } \\
\text { attending distance } \\
\text { learning }\end{array}$ \\
\hline $\mathrm{N}$ & 78 & 80 \\
\hline Minimum & 26 & 1 \\
\hline Maximum & 60 & 7 \\
\hline Mean & 38,40 & 2 \\
\hline
\end{tabular}




\begin{tabular}{|l|c|c|}
\hline $\begin{array}{l}\text { Std. } \\
\text { Deviation }\end{array}$ & 7,508 & \\
\hline \\
\hline Mode & 42 & 1,407 \\
\hline
\end{tabular}

\section{c. Instrument}

The student's collect data was done through

1. an open answer questionnaire where it was requested the 3 main reasons that took the inquired to choose distance learning.

- Which had been the three (3) main reasons that had taken him/her to choose distance learning
1 .
2.
3.

2. a qualitative scale to answer our question:

How do you evaluate the eLearning, in general?

\begin{tabular}{|c|c|c|c|c|}
\hline Very Good & Good & Indifferent & Sufficient & Poor \\
\hline & & & & \\
\hline
\end{tabular}

\section{Results}

The presentation of results is going to be done by the following way:

- Presentation and meaning of the answers' category;

- Analyses the frequency of the different categories by order of reason;

- Analyses the frequency of the different categories, in the all and by gender.

- Analysis of percentages of evaluations' categories

\subsection{Presentation and meaning of the answers' categories}

To analyse the answers through the questions asked to students we used the technique of content analyses. From this data treatment we've got the following analysis's categories:

Figure 4 Answer Categories

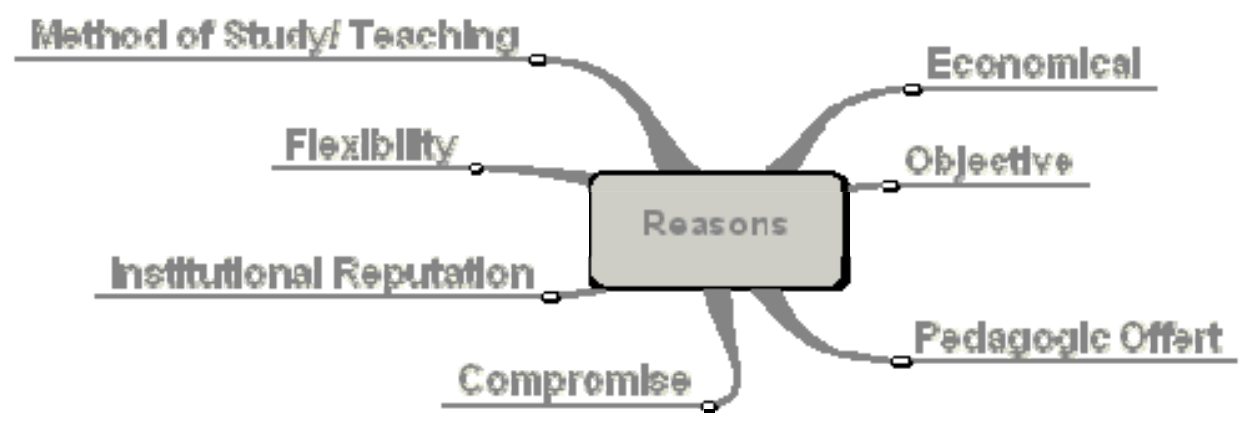

The following table represents the meaning of each one of the categories. So, 
Table 3 - Categories

\begin{tabular}{|c|c|c|}
\hline Categorie & What it means & Example \\
\hline Compromise & $\begin{array}{l}\text { Category of answer that is related } \\
\text { with conciliating professional life, } \\
\text { family life and study. }\end{array}$ & $\begin{array}{l}\text { To be able to work and to study; } \\
\text { Having small children. }\end{array}$ \\
\hline Objective & $\begin{array}{l}\text { Category of answer related with } \\
\text { personal and professional needs }\end{array}$ & $\begin{array}{l}\text { Professional Qualification; } \\
\text { Wanting to take a degree; } \\
\text { Personal Valorisation. }\end{array}$ \\
\hline $\begin{array}{l}\text { Method of } \\
\text { Study / } \\
\text { Teaching }\end{array}$ & $\begin{array}{l}\text { Category of answer related with the } \\
\text { way to study in this system of } \\
\text { education }\end{array}$ & $\begin{array}{l}\text { Self-learnig; } \\
\text { Innovating System. }\end{array}$ \\
\hline $\begin{array}{l}\text { Pedagogic } \\
\text { Offer }\end{array}$ & $\begin{array}{l}\text { Category of answer related with the } \\
\text { courses and issues offered }\end{array}$ & $\begin{array}{l}\text { Interesting course; } \\
\text { Realistic pedagogic proposal. }\end{array}$ \\
\hline Economical & $\begin{array}{l}\text { Category of answer related with the } \\
\text { economic aspects to study in this } \\
\text { system of education. }\end{array}$ & $\begin{array}{l}\text { Economic factor; } \\
\text { Costs; } \\
\text { More economic. }\end{array}$ \\
\hline Flexibility & $\begin{array}{l}\text { Category of answer related with } \\
\text { factors that become more accessible } \\
\text { on this system of education, related } \\
\text { with the possibility to manage the } \\
\text { time and the contents in accordance } \\
\text { with the rhythm of the students }\end{array}$ & $\begin{array}{l}\text { Time management. } \\
\text { Not to be forced to attend lessons; } \\
\text { Health issues; } \\
\text { Accessibility to the contents. }\end{array}$ \\
\hline $\begin{array}{l}\text { Institutional } \\
\text { Reputation }\end{array}$ & $\begin{array}{l}\text { Category of answer related with the } \\
\text { image of the institution }\end{array}$ & $\begin{array}{l}\text { Confidence in the education } \\
\text { implemented by the University; } \\
\text { Scientific and pedagogical quality of } \\
\text { the University professors. }\end{array}$ \\
\hline
\end{tabular}

\subsection{Analysis of the different categories frequency, for order of reason}

The following results give us the idea of the importance of each category when choosing this kind of education. As it can be seen on table 4, the first reason is the Flexibility which means the possibility of managing the time, contents and spaces according to needs and rhythms; followed by Compromise, that this system gives to whom needs it. Then, we find reasons related with a need for professional and personal valuations - Objective.

Table 4 First reason

\begin{tabular}{lrr}
\hline \hline & Frequency & Percent \\
\hline Flexibility & 41 & 51,3 \\
Compromise & 24 & 30,0 \\
Objective & 8 & 10,0 \\
Economical & 3 & 3,8 \\
Pedagogic Offer & 2 & 2,5 \\
Method of Study / Teaching & 2 & 2,5
\end{tabular}




\begin{tabular}{lrr} 
Total & 80 & 100,0 \\
\hline \hline
\end{tabular}

Concerning the reasons, we found this answer pattern.

Table 5 Second and third reason

\begin{tabular}{|c|c|c|c|c|c|}
\hline \multicolumn{3}{|c|}{ 2nd Reason } & \multicolumn{3}{|c|}{ 3rd Reason } \\
\hline & Frequency & Percent & & ncy & Percent \\
\hline Flexibility & 26 & 34,2 & Objective & 20 & 27,8 \\
\hline Compromise & 15 & 19,7 & Method of Study / & & \\
\hline Objective & 12 & 15,8 & Teaching & 18 & 25,0 \\
\hline Economical & 10 & 13,2 & Flexibility & 16 & 22,2 \\
\hline Method of Study / & & & Compromise & 11 & 15,3 \\
\hline Teaching & 8 & 10,5 & Pedagogic Offer & 3 & 4,2 \\
\hline Pedagogic Offer & 4 & 5,3 & Economical & 2 & 2,8 \\
\hline $\begin{array}{l}\text { Institutional } \\
\text { Reputation }\end{array}$ & 1 & 1,3 & $\begin{array}{l}\text { Institutional } \\
\text { Reputation }\end{array}$ & 2 & 2,8 \\
\hline Total & 76 & 100,0 & Total & 72 & 100,0 \\
\hline
\end{tabular}

However, in spite of the three main remained the same, in Reason 3 - the Objective category goes to first place and category Method of Study/ Teaching goes to second place. We must say that only in Reasons 2 and 3 appear the Institutional Reputation category.

In conclusion, we found this global numbers - Table 6

Table 6 Reason Total

\begin{tabular}{lrr}
\hline \hline & Frequency & \multicolumn{1}{c}{ Percent } \\
\hline Flexibility & $\mathbf{8 3}$ & $\mathbf{3 6 , 4}$ \\
Compromise & $\mathbf{5 0}$ & $\mathbf{2 1 , 9}$ \\
Objective & $\mathbf{4 0}$ & $\mathbf{1 7 , 5}$ \\
Method of Study / Teaching & 28 & 12,3 \\
Economical & 15 & 6,6 \\
Pedagogic Offer & 9 & 3,9 \\
Institutional Reputation & 3 & 1,3 \\
Total & 228 & 100,0 \\
\hline \hline
\end{tabular}

As previously saw the Flexibility category divides in the items Time, Space, Contents, Rhythm and General Category.

The following graphics are related to Category Flexibility within the 5 reasons: 


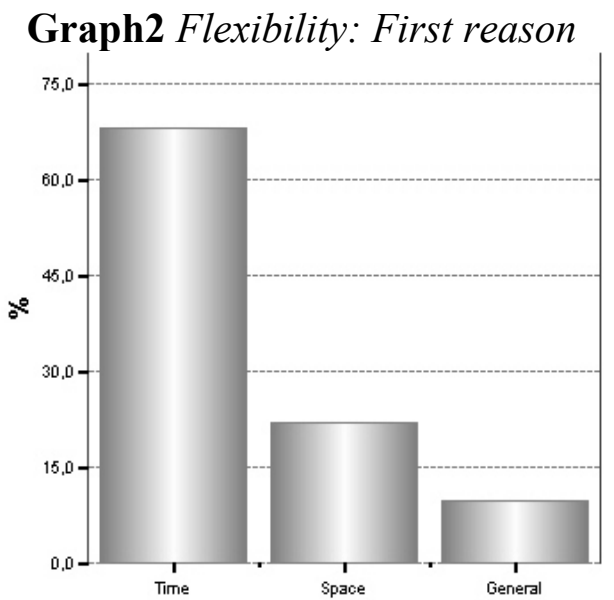

We can see here that Time is essential for choosing distance learning. Following is Space, meaning that there are no other options in the place where they live or not having to go there often because of professional reasons. The General category is related with concepts as "more freedom", "more independence", "more facility in learning" that depends on the others categories.

Graph 4 Flexibility: Second and third reason
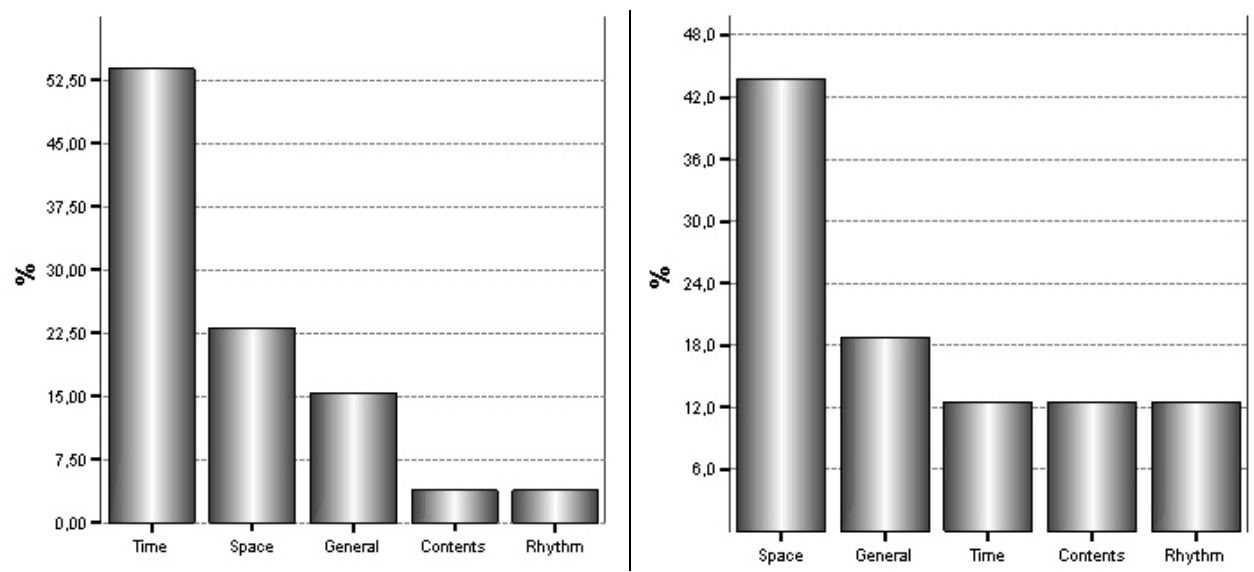

The back graphics belong to the same category, but of the reasons 2 and 3. There we can verify that two new categories come up - Contents and Rhythm. That begins to exist a valuation of the items Space and General and a reduction of the item Time.

\subsection{Analysis of the different categories frequency, in the total and by gender}

After grouping the different answer categories got, we tried to verify how these categories are divided concerning gender. Table 7 represents the results obtained crossing these variables. 
Table 7 Reason - Total * Gender

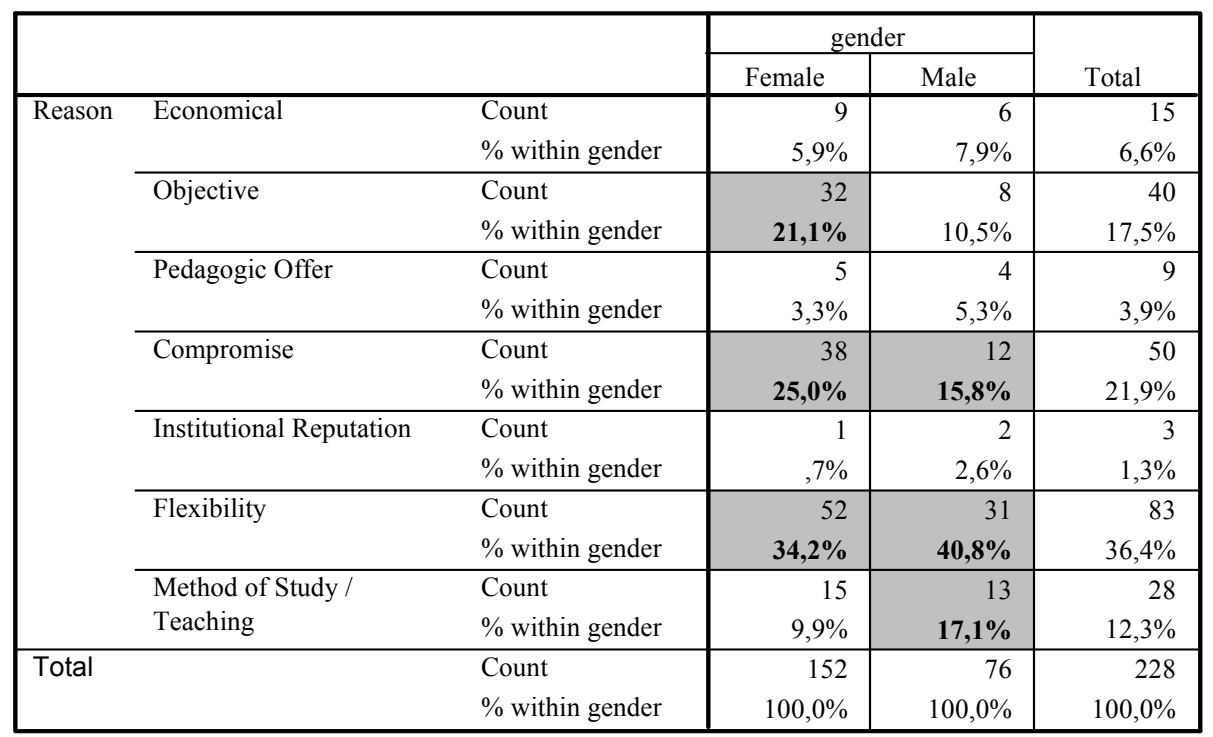

As we can see the answer pattern is a little different between groups. Both groups put the Flexibility in first place; in second place women put the Compromise and men the Method of Study/ Teaching. In the third place women put the Objective and the men Compromise.

\subsection{Analysis of percentages of evaluations' categories}

Our results have just 3 evaluative categories - Very Good, Good and Sufficient. Those are distributed in the following way - Table 8

Table 8 Evaluation

\begin{tabular}{lrr}
\hline \hline & Frequency & Percent \\
\hline Good & 47 & 62,7 \\
Very Good & 20 & 26,7 \\
Sufficient & 8 & 10,7 \\
Total & 75 & 100,0 \\
\hline \hline
\end{tabular}

The next step was to verify how the evaluation that was made in this education system behaved face to the pointed reasons to its choice - Table 9 
Table 9 Reasons * Evaluation

\begin{tabular}{|c|c|c|c|c|c|c|}
\hline & & & \multicolumn{3}{|c|}{ Evaluation } & \multirow[b]{2}{*}{ Total } \\
\hline & & & Sufficient & Good & Very Good & \\
\hline \multirow[t]{14}{*}{ Reason } & Method of Study / & Count & 2 & 15 & 10 & 27 \\
\hline & Teaching & $\%$ within Evaluation & $9,1 \%$ & $11,2 \%$ & $16,7 \%$ & $12,5 \%$ \\
\hline & Flexibility & Count & 5 & 52 & 21 & 78 \\
\hline & & $\%$ within Evaluation & $22,7 \%$ & $38,8 \%$ & $35,0 \%$ & $36,1 \%$ \\
\hline & Institutional Reputation & Count & 0 & 0 & 2 & 2 \\
\hline & & $\%$ within Evaluation &, $0 \%$ &, $0 \%$ & $3,3 \%$ &, $9 \%$ \\
\hline & Compromise & Count & 6 & 27 & 14 & 47 \\
\hline & & $\%$ within Evaluation & $27,3 \%$ & $20,1 \%$ & $23,3 \%$ & $21,8 \%$ \\
\hline & Pedagogic Offer & Count & 0 & 5 & 3 & 8 \\
\hline & & $\%$ within Evaluation &, $0 \%$ & $3,7 \%$ & $5,0 \%$ & $3,7 \%$ \\
\hline & Objective & Count & 6 & 25 & 9 & 40 \\
\hline & & $\%$ within Evaluation & $27,3 \%$ & $18,7 \%$ & $15,0 \%$ & $18,5 \%$ \\
\hline & Economical & Count & 3 & 10 & 1 & 14 \\
\hline & & $\%$ within Evaluation & $13,6 \%$ & $7,5 \%$ & $1,7 \%$ & $6,5 \%$ \\
\hline \multirow[t]{2}{*}{ Total } & & Count & 22 & 134 & 60 & 216 \\
\hline & & $\%$ within Evaluation & $100,0 \%$ & $100,0 \%$ & $100,0 \%$ & $100,0 \%$ \\
\hline
\end{tabular}

As is seen who evaluates this educational system as Sufficient points out as the main reasons, in first place the Compromise and the Objective. In last place the Flexilibity. Who evaluates with Good or Very Good has an identical behavior in the first two choices - Flexibility and Compromise. The third reason to the Good evaluation is the Objective. For the Very Good evaluation is the Method of Study/ Teaching.

\section{Conclusion}

Deep changes of economical and social levels, the globalization implications, as well as the technologic development came to modify the societies' panorama and putting new challenges. The continuous acquisitions of knowledge and competences have become compulsory to guarantee the integration and responsibility of people in the society where they belong. Also in order to guarantee the development and a sustainable economy.

It is urgent the investment on education and formation of people in a way to give them the knowledge and the competences needed to perform now and in the future their functions. This investment cannot be only at the beginning. On the contrary it must be done along the individuals' life. For those who are already on the work market, having already a personal and family life the Access to this kind of formation becomes hard. It is here that Distance learning has a main role (Goulão, 2000) .

So, to check in which measure this system answers to the needs of this kind of people we've done this work which scope was to know the main reasons which take people to choose Distance learning. We used an Open Question so they could say the three main reasons of that option.

The analyses of the answers leave us to conclude that the individuals turn to Distance Learning in a voluntary way. This option may also be the result of an institutional imposition or even a geographic one. We cannot forget that the main users are persons who already have a professional life and, often, a family too.

The answers' treatment allowed the identification of reasons that made the distance learning role as a way of promoting the equality of opportunities. As an example of 
this aspect is found the category Objective - category of answer related with personal and professional needs, Economical - Category of answer related with the economics aspects to study in this system of education and Flexibility - category of answer related with factors that become more accessible on this system of education - Time, Space, Contents, Rhythms and General aspects.

The flexibility is one key element in the lifelong learning (Klein \& Osborne, 2007). Flexibility connected to the necessity of choosing between time and spaces depending on the students' or on the boss' necessities. It was found this kind of evidences in categories, like we sad previously as Flexibility - category of answer related with the possibility to manage the time and the contents in accordance with the rhythm of the students, Compromise - category of answer that is related with conciliating professional life, family life and study, Method of Study / Teaching - category of answer related with the way to study in this system of education and Economic Category of answer related with the economic aspects to study in this system of education.. It was found answers that join the categories Pedagogic Offer and Institutional

\section{Reputation.}

The analyses of the answers leave us to conclude the three main reasons to choose the distance learning are the Flexibility, the Compromise and the Objective. Among the items making part of the category Flexibility the one which has main evidence is Time.

Both, male and female, agree that the main reason to choose the distance learning is the Flexibility. For female, the others main reasons to choose this system are the Compromise and the Objective. In case of the woman, (...) the deliberate choice for the distance education system is recognized in the literature because it allows reconciling, among other aspects the family and the work. In the women's case, since many of the domestic tasks are committed to her, this education system becomes an important ally to value their formation (Goulão, 2008).

For male, the second reason was the Method of Study / Teaching and, the last one, was the Compromise.

So, in one hand, the reasons to choose the distance learning system that were presented by our sample, especially the three previously mentioned, in the other hand the high evaluation made to this system, make stronger the relevancy idea of this learning system on the promotion of lifelong learning globalization as well as it becomes an important ally in the politics' implementation of the social inclusion and the economic competitively.

This way, the results got strength our idea that Distance Learning is a strong allied, allowing in many cases, to lifelong learning.

\section{References}

Aretio, L.G. (2002). 'La educación a distancia: De la teoría a la práctica', Barcelona, Ariel Educación Bourgeois,E \& Nizet,J.(1999). 'Apprentissage et Formation des adultes' (2 ${ }^{\mathrm{a}}$ ed.),coll.Éducation et Formation, Paris, PUF

Costa Silva, A.M. (2000).“ Da formação de adultos ao adulto em formação” in Revista GalegoPortuguesa de Psicoloxia e Educación, nº4 (vol.6), pp.666 - 677

Council of the European Union (2006). 'Adult learning- It Is Never Too Late To Learn'. Retrieved on 20 January 2007 from : http://eurlex.europa.eu/LexUriServ/site/en/com/2006/com2006_0614en01.pdf

Council of the European Union (2008). 'Draft 2008 joint progress report of the Council and the Commission on the implementation of the 'Education \& Training 2010' work programme "Delivering lifelong learning for knowledge, creativity and innovation" - Adoption', Council 
of the European Union. Retrieved on 15 February, 2008 from http://ec.europa.eu/education/pdf/doc66 en.pdf

Cross,K.P.(1981). 'Adults as learners', San Francisco, Jossey-Bass

European Commission (2001),'Making a European area of lifelong learning a reality', Commission of the European Union. Retrieved on 22 January, 2008 from http://ec.europa.eu/education/policies/lll/life/communication/com_en.pdf

European Commission (2008), 'The European Qualifications Framework for Lifelong Learning (EQF)', European Communities.Retrieved on 5 Jun, 2008 from http://ec.europa.eu/education/policies/educ/eqf/eqf08_en.pdf

European Parliament (2006),' Recommendation of the European Parliament and of the Council of 18 December 2006 on key competences for lifelong learning', Official Journal of the European Union, L394/10. Retrieved on 10 August, 2007 from http://eurlex.europa.eu/LexUriServ/site/en/oj/2006/1_394/1_39420061230en00100018.pdf

Goulão, M. F. (2000). 'Distance Education and the adults' formation. 'Revista Galeco-Portuguesa de Psicoloxía e Educación 4(6), pp 657-666

Goulão, M. F. (2002). 'Open and Distance Learning - Cognition and Affectivity'. Ph.D. diss., Universidade Aberta [In Portuguese]

Goulão, M.F. (2008). 'Distance Learning and Gender', in Gregory T. Papanikos,eds, Issues on Education and Research - voll, Atenas: ATINER

Klein,B. \& Osborne,M.(2007). 'The concepts and Practices of Lifelong Learning', London, Routledge Knolews,M.(1990).' L'apprenant adulte: Vers un nouvel art de la formation', Paris, Editions Entrentes

Malglaive,G.(1995). 'Enseigner a des Adultes' (trad.), col.Ciências da Educação, Porto, Porto Editora [in Portuguese]

Rogers,C.R.(1985). 'On Becoming a Person' (trad.), Lisboa, Moraes Editores [in Portuguese]

Statistics Portugal (2008). Education and Training of Adults Survey, Lisboa, INE

Unesco/Col. (2005). 'Perspectives on Distance Education: Lifelong Learning \& Distance Higher Education', Paris, UNESCO 